\title{
Critical Entitlement Theory on post-missionary paternalism in the Church of Christ in Zimbabwe
}

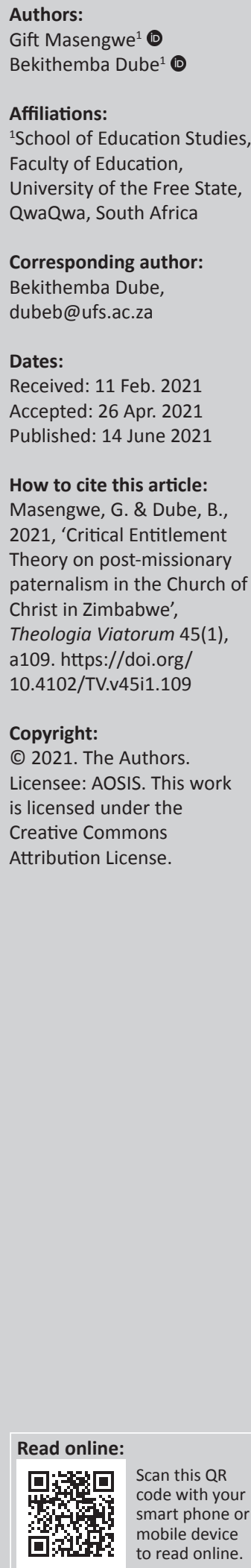

The dynamic of power troubles are the doing and thinking and that knowledge is always contingent, standing above the abyss, as stated by Prof. J. Jansen in 2009. The issue of entitlement affected the Church of Christ in Zimbabwe (COCZ) at the onset of the third millennium. Leadership vacuum at the departure of missionaries led individuals to assume identities and hierarchies believed to have been interwoven into the polity and governing ideology of the COCZ. This connoted towards power, privilege and position for someone to benefit on church investments. The article suggests use of the critical Entitlement Theory (CET) to assess how contemporary situations at mission stations affect local churches and communities. Black elites who took over have created tensions and contradictions in churches by hiring persons who do not question their actions and words and persons who do not have an appreciation of the production and implementation of the church's governing laws. Critical Entitlement Theory assumes that the privileged ownership and administration theses' that date back to white privilege in the colonial church created this problem. This ethnographic study discloses how a new interdisciplinary thinking on equity and justice to local Christians can rise to own and manage mission stations in their local congregations.

Keywords: Church of Christ in Zimbabwe; mission stations; Critical Entitlement Theory; critical denominational studies; missionary paternalism; African philosophy.

\section{Introduction}

This study is reflective and ethnographic and attempts to establish a theory called Critical Entitlement Theory (CET). This theory is an ethical-theological-hermeneutical analysis of how power, privilege and position are used in church scholarship and because of persistence of institutionalised missionary dogma, ideology and legality in the Church of Christ in Zimbabwe (COCZ). Missionaries especially those who came from America under Central Africa Mission (CAM), such as John C. Pemberton, did a lot for Zimbabwe. Unfortunately, some American as opposed to New Zealander missionaries, such as Garfield Todd, did not believe that Africans were better owners and managers of school and hospital investments at mission stations. Home mission boards recruited, supported and placed missionaries in the two mission fields that eventually became divided between American and New Zealand missionaries. Their legacies continue to be experienced along lines of foreign and local funding and support. Dadaya mission stations as opposed to Mashoko became open to local leadership and accountability at independence, whereas Mashoko remained personalised (Savage 1980). In the Church, institutions were designed to reproduce and maintain missionary supremacy that systematically excluded African Christians through institutional marginalisation (Masengwe, Chimhanda \& Hove 2019:278-289). At the departure of missionaries, the feature of religious order became ingrained in mission stations in covert ways. The running of children's homes and villages, for instance, in Chiredzi by the Hippo Valley Christian Mission, has implications for religious, spiritual, theological, financial, cultural, ethical and ecclesiological success. The institutions are directly funded by departed missionaries who continue to control how activities are carried out in the country. This has influenced how locals fight over church buildings in Chiredzi and went to court or active disfellowshipping of congregations by leaders aligned to national factions such as Mashoko and Sombabhula Conference groups $^{1}$ (Masengwe \& Chimhanda 2019). Decisions seem to be delivered by courier from former missionaries and read to local Christians in perpetuation to deep inequalities between them and black elites, who are usually professionals or specialists (Masengwe \& Chimhanda 2020:1-10). This article problematises ethical-legal, doctrinal-ideological, religious-cultural and spiritual-political 1.Conflicts were registered in Zaka (Jerera and Svuure Churches) and Mashoko, Bikita area (Mashoko Churches) and 27 schools running
under Hippo Valley Christian Mission (Mukanga) and clinics and hospitals registered under 'As He Is' in the same area (Mashoko Hospital). 
discourses that refuse to account for the inhuman treatment of local people by missionaries (Masengwe \& Magwidi 2021). Proxies who took over from missionaries were groomed to perpetuate the missionary attitude to local people.

\section{Plan of the argument}

The CET in COCZ is discussed through threefold critiques of 'power, privilege and position'.

Entitlement on mission stations here cannot be succinctly stated, except their denial to create an indigenous church. This article attempts to capture this for contemporary Christian audiences not initiated in colonial-missionary history. Progress in the church is intermittently connected to statuses of mission stations. This article unapologetically presents a theoretical description, comparative illustration and applicability of CET in the COCZ.

In section 'Paternal inheritance in the Church of Christ in Zimbabwe', the article engages elimination, conservation and reconstruction as contemporary discourses of mission station entitlements. Reconstruction takes into account how 'power, privilege and position' are historically constituted using capitalism, liberalism and individualism as constitutive categories that conserve, reconstruct or eliminate the COCZ governing ideology (Masengwe \& Chimhanda 2020). Total elimination of autonomy can be replaced by its total opposite, heteronomy, which cleaves towards African philosophy (Masengwe 2020; Masengwe \& Magwidi 2020).

The section entitled 'Towards Critical Entitlement Theory in the Church of Christ in Zimbabwe' explores broader and diverse issues of ownership and administration to appreciate lack of material on CET in colonial history of missions in the COCZ. It generates themes that are elaborated and briefly commented on in the section 'Paternalism and the constitution in the Church of Christ in Zimbabwe'. They relate to the purpose of the church in society, criticising personalised and unaccountable family ministries (Masengwe \& Magwidi 2021). Use of CET here does not prescribe or proscribe how to assess the canonical doctrines of property ownership in the COCZ, but to disprove foundations of austere doctrines of colonial missions. This requires us to discuss the CET.

\section{Theoretical background}

Critical Entitlement Theory is being developed to assess the legacy and history of mission churches in Zimbabwe. A church is 'ekklesia', which means 'called out ones' or 'assembly' (Banana 1991:75) of the 'saved ones' (Ac 19:39). Christians act in keeping with the purpose of interpreting 'God's will in order to align their lives and the lives of those around them to God's will' (Gundani 2008:124). In Athens, Greece, 'assembly' represented a meeting of free citizens convening to decide on state laws, elections, appointing judges, declaring wars, making treaties, electing generals, assigning troops for military operations and allocating funds. William Barclay (1955) said:
Two things are interesting to note. First, all its meetings began with prayer and sacrifice. Second, it was a true democracy. It was an assembly where everyone had an equal right and an equal duty to take part. (p. 34)

Greek 'ekklesia' was Christianised to mean the assembled congregation of God's people through faith in Jesus Christ. Interchangeably, it refers to congregation or denomination (Williams 2003:171). Thus, a church is (M'Clintock \& Strong 1969):

[A] visible body of Christ on earth ... a house of worship, a denomination, a congregation of a denomination or the establishment of a church in a nation or the sum-total of denominations. (p. 322)

It is a living organism and a functioning organisation (Van Reken 1999). God resides there, but it is run by humans. Mission stations are instruments used by principled heralds to convey this grace to the world (Dulles 1987:76). Mission stations are places where missionaries resided and carried out their activities in given areas. They facilitated colonisation. For the COCZ, they had three groups: American conservatives at Nhowe Mission (Mashonaland East), American liberals at Mashoko Mission (Masvingo) and New Zealanders at Dadaya Mission, Zvishavane (Midlands) (ColenBrander Avenue Church of Christ [CBACC] 1948-1965). Religious communities affected the real lives of indigenous populations through charities, education and health (Bowen 1996:70). Their funding come from donations and state funds and members understand future accountability as the basis of how they handle their Christian call (Dulles 1987:96). Authentic churches use relevant and impactful modes of ministry (ed. Villa-Vicencio 1986:viii) not hindered by governing ideologies (Halencreutz 1998:101-102) or existential issues to liberate people. This article criticises missionary unilateralism and black professionals' entitlement to mission stations.

Firstly, entitlement uses 'power, privilege and position' by elites because mission entities are family enterprises (Masengwe \& Magwidi 2021). This negates the assertion that the COCZ is not a denomination, requiring us to use critical denominational studies (CDS) to expose narrative instruments used on their entitlements. Missionary paternalism is perpetuated by contemporary references to their former glories. Critical denominational study criticises the use of appointees in ecclesial structures to perpetuate missionary paternalism that interferes with the context and particularity of black worship. Revolutionising this begins with radical dissatisfaction with the status quo, embracing its antithesis: freedom and liberation (Calmore 1992:62). Both CET and CDS combine to debunk dominant conceptions of perpetual white missionary ownership and administration of mission stations through ethical-legal calls to accept subjective experiences and living conditions of Africans.

Secondly, unilateralism continuously discriminates or excludes locals from mission stations (Masengwe \& Magwidi 
2021). They are dominated by chosen families, which replays domination, inequality and injustice from larger capitalist machineries interested in profit, accumulation, property and labour exploitation in globalised-liberal-capitalist models called 'Symbols of a New Humanity' (Cornell \& Panfilio 2010:125-149). Mission stations thus become capitalist investments connected to paternal founders. Church ideals are sold out for foreign support in the world order of global democracy, information and technology and capital accumulation (Mills 2003). These ideals lay an oppressive foundation that alienates newer Christians from full adoption. Entitlements become reified through formalist modes of connection to missionaries, with utter disregard for ordinary believers (Masengwe, Machingura \& Magwidi 2012). Reification here is idolisation of missionaries that disenfranchises new members. This article thus calls for eradication of foreign churches in Africa that promote yesteryear glories to disenfranchise contemporary believers.

Lastly, CET examines transformation of the church into an indigenous institution. It deals with persistent idiosyncrasies of black Christians as objects rather than subjects. Past narratives hinder such Christians to go beyond pervasive and brutal structures of oppression in socially engineered ecclesial ideologies. Rectification of the racialised 'past' was not in replacing white faces with black faces but radical transformation capturing the hermeneutic of existentialism in these pervasively colonised African spaces. The COCZ through the 2015 'historic bridge' tried to break away from the past by crafting a new constitution (COCZ 2015). This new foundation transitions the 'foreign-owned missionary COCZ to an indigenous owned COCZ'. It reduces past contrasts by engaging with local Christians. This accepts difference to increase dignity, freedom and equality in a multicultural, self-determined African Church (Masengwe \& Chimhanda 2019, 2020). As a result of the haphazard transfer of mission stations at the departure of white missionaries, not conterminous with majority of members, the COCZ is currently in the middle of the metaphorical bridge, failing 'to transform from a movement into Church' (Magwidi 2019).

\section{Paternal inheritance in the Church of Christ in Zimbabwe}

Entitlement labels are used in conserving or eliminating others from COCZ mission stations. Discourses are narrowed or expanded in contemplation of theoretical reconstruction of institutions that benefit individuals. Mission stations are legal entities that can be reconstructed in performing church missions. Unfortunately, paternal inheritance pushes us to choose between eliminativism, conservativism and reconstructivism using normative, ontological, conceptual and methodological questions below, namely:

- What is the value of power, privilege and position in contemporary ownership and administration of mission stations in the COCZ?
- Is there certitude on entitlement to mission stations in the COCZ?

- What is the 'critical' view of 'entitlement' as opposed to 'responsibility'?

- How does CET identify use of power, privilege and position on mission stations in the COCZ?

\section{Eliminativism}

Thoughts and feelings of elimination interestingly are pampered by both mission administrators and ordinary Christians (Masengwe \& Magwidi 2021). The contemporary status of mission stations using missionary paternalism help us to understand how entitlement contributed to historical divisions of mission societies such as the American and the New Zealander Missionary groups (Dadaya) and the subgroups within the American group of instrumental (Mashoko) and non-instrumental (Nhowe) churches. They used paternal privilege to advance racism, ethnocentrism and tribalism, rather than Martin Luther King Junior's hope that his children would be judged ... by the 'content of their character' (Marle 1968:15). With CET, institutional boards cannot be appointed through familial adoption but by modern elite standards as stated by Chikwanda, a male paster at the Tshovani Church of Christ. Standards are usually not ambiguous; they reward hard-working individuals. Paternalists created dubious instruments that need to be eliminated. Eliminativism thus critically disaffirms the status quo but cannot claim to totally abandon paternalism, which must be collectively applied to reduce retrogressive effects of privatised practices in COCZ entities today. However, there are no unified perceptions to these critiques.

\section{Conservativism}

Conservativism advances the idea that names and certain labels need to be retained, including legal protection, whilst reviewing paternal attitudes, practices and systems. Wanton practice of eliminativism thus can be a serious error as missions originated with individuals and have shaped identities and dignities of families. Abstractions in Restoration churches unfortunately 'evoked a false sense of continuity between past, present and future and had helped to preserve [paternal] injustice' (Williams, Foster \& Blowers 2013:3). Paternal identities have psychological and material relevance to mission life, providing its ethical and moral resources to predict the future COCZ. This means paternalism remains a viable and valuable concept on contemporary statuses of mission stations in the COCZ despite its attack and criticism for oppressing women, girls and children.

Conservativism ensures the status quo is maintained. In the Church of Christ, liberals and conservatives contested, with liberals winning (Garrison 1961:35) and determining how the church engaged on public life issues of peace and justice, war, identity and difference, and human rights (Williams et al. 2013:380). Creativity is encouraged to those who did not get a hill start in life. Paternalism is unfortunately nuanced 
because one rides on parental historical opportunity rather than personal aptitude. Paternalism reconstructs history, militating against repairing serious past disparities and inequalities in families that support paternal greed in Church. Using paternal privilege fails the religious fiction of paternal equality in Jesus Christ as it intractably aligns itself with racial history of exploitation, subordination and discrimination. Accepting paternalism runs the risk of reinforcing harmful stereotypes that are insensitive to particular identities in different church groups. Henceforth, conservativism is critical for addressing paternal injustices; hence, it must be upheld for its positive contributions towards engagement in the COCZ.

\section{Reconstructivism}

Reconstructivism is not a new thing in the COCZ as 'the movement had never been uniform, but had included differing, even conflicting ideas and views from its very beginning' (Williams et al. 2013:3). This assumes that religious concepts need to be continuously reconstructed to address the legacies and ramifications of missionary history, mindful of errors of greed that subordinated local converts to demeaning and dehumanising treatment by church leaders. It helps to confront and embrace concrete differences between people. It counterbalances conformity, reductionism and sameness emphasised by dogmatic Christian thinking. Equality in structural power demands plurality towards paternally constructed issues faced by religious institutions in contemporary Africa. Confrontation must be done mindful of paternalism, classicism, elitism and ageism traps tied to conceptualisations of postmodernist human relations (Masengwe \& Chimhanda 2020; Masengwe \& Magwidi 2021). Paternalism brings stability in human relations henceforth it needs to be approached conscious of its effects on boys and girls in the construction of their worlds as argued in the next section of this article.

\section{Towards Critical Entitlement Theory in the Church of Christ in Zimbabwe}

Social constructions of paternalism and entitlement are insidiously imbedded in ecclesial systems of the COCZ and are also culturally produced and reproduced amongst the Shona and Ndebele. Critical Entitlement Theory has an explicitly activist dimension in its aspirations that leverages on knowledge production to transform paternal relationships by reforming ways in which entitlement is historically entrenched in the racial marginalisation of the African Christians in the COCZ. This leads us to six tentative theoretical elements of CET referenced in challenging mainstream religious knowledge from America that must be transformed. These themes are organising principles that lead towards new debates on paternal thinking in the COCZ.

\section{Critiquing conservative transformation in the Church of Christ in Zimbabwe}

Insistence on Restoration faith accepts exclusive capitalistic, liberalist and individualist tendencies (Masengwe \&
Chimhanda 2019, 2020). Critical Entitlement Theory attempts to create a new and radical account of paternalism that departs from, and is incomparable with, western liberal paternalism. Radical paternalism sides with the marginalised whereas scholarship of conservative liberal paternalism sides with the status quo. Causation (power), procedure (privilege) and locus standi (position) are normal approaches. Using influence, status and affluence to undermine identities and dignities is deviation from fair and impartial ways of treating other humans by whom we share jobs, services, spaces and resources. Paternalism of that kind is systematically ingrained in mission cultures, reinforced by appointment methods and reproduced through entitlements.

This subordinates and traps African Christians into corollary disorientation from the historically and legally connected members (Masengwe et al. 2012). Religion, which is in the sacred, may not be defined as qualitatively different from paternalism in liberal scholarship because of these ideological differences (Masengwe et al. 2019:278-289). Paternalism however is imbedded in religious power and normative assumptions with which religion organises human relations in Church. This leads us to the indeterminacy of entitlement on Hippo Valley Christian Mission and associated mission stations such as Mashoko, Devure, Chidamoyo and Makonde (Masengwe 2020).

The theoretical and intellectual disjuncture between religion and paternalism may be indeterminable, however, frustration with religious pedagogy of western liberalism that produces false concepts of autonomy as depoliticised and technocratic animates the CET. Autonomy in the COCZ is individualistic, liberalistic and capitalistic and therefore colonial, which veers the Church away from its sacredness because instruments being applied are foreign and secular. The concept was borrowed from western business practices (Casey 2004:490) to complete the reformation of the 16th century (Williams et al. 2013:1) by adhering to sola scriptura (Dowling 2011:118). Autonomy disorientates untitled families and hence 'minimised how locals shared leadership functions with missionaries' (Masengwe \& Magwidi 2021:4) at mission stations. Systematic discrimination is unnoticeable when things work well, but CET proposes to reinforce moral engagement on these structures to incorporate African contributions as Africans received raw deals in all of their past. 'Dependent African church leaders became disoriented emotionally and economically' (Masengwe \& Magwidi 2021:4). Autonomy is ingrained in the banal nature of systematic subjugation that objectifies the black person. Religion thus falls into the apologetic ambivalence of missionary politics that continue to produce contradictions on African communities (Crenshaw 2000:21-24).

\section{Uniformity versus diversity in the Church of Christ in Zimbabwe}

The Restoration Movement was formed with an emphasis on five domineering marks of identity, namely, Christian unity, 
evangelism, restoration, peace and justice (DeGroot 1956:2; Dowling 2011:118; Williams et al. 2013:380). Unity did not affix people into single human experiences based on uniformity but accepted categories of human identity such as gender, age, class, ethnicity and race. Elites clamour for uniformity and not diversity in attempting to define belonging and not belonging using the essence of sameness and difference that creates convergence on monolithic accounts of African identity and destroys divergence as apostasy (Masengwe et al. 2019:278-289). Critical Entitlement Theory is a critical attempt to redefine experiences of African communities and especially unitary experiences of black people. This counters monolithic perspectives that ignore different concerns of African Christians (Masengwe et al. 2012). African identities need to be strategically articulated without arrogating itself to universalising African voices. The CET criticises paternalism in COCZ mission stations that attempt to create a univocal black experience as a static, reified and fetishized experience.

In this way, the COCZ cannot use an essentialist approach to policies that fail to recognise the tentativeness of identity and relations (Masengwe 2020). It is not akin to issues of identity amongst its people (Mills 1983:16), including multiplicity of names churches are called (Dowling 2011:120-121). Magwidi (2019) sarcastically says COCZ congregations are in a deeper identity crisis because 'church names are like surnames'. The crisis arises from persistent reliance on nuanced past categories in their legislative processes. Critical Entitlement Theory criticises this inherent rigidity with fondness for uniformity, collectivisation and abstraction that oppresses continually (Masengwe et al. 2012), without encouraging team spirit and kinship realities in shaping history and identity of black Christians.

\section{An intersectional approach in the Church of Christ in Zimbabwe}

Critical Entitlement Theory understands that people are defined by more than one category because we 'are simultaneously raced, classed and gendered' (Modiri 2011:418). It is the intersection of these categories that induce discrimination and oppression. This study examined how intersections of race, sexuality, class, gender, religion, nationality, culture, (dis)ability and sexual orientation induce domination and prejudice (Masengwe et al. 2019:278-289). The CET identifies and analyses how African Christians are disadvantaged by use of entitlement on mission stations if there is no critical engagement with stated differences. Critical engagement with minority groups helps to redress church laws that justify religious oppression (Crenshaw 1989:139, 1991:43; Hooks 1981; Wing 2008). Critical Entitlement Theory criticises oversimplification of human experience that produces fixed categories of identity found in various church settings (Masengwe et al. 2019:278-289). It engages in multiple attempts to address social ills in human life (Crenshaw 2011:43; Delgado \& Stefanie 1993:79; Hutchinson 2004:53). It criticises emphasis on sameness rather than difference because there are no two people who are the same including monozygotic twins. The national laws continue to change to empower marginalised groups whose categories also continue to change. These categories demonstrate relevance of intersectional analyses that need interrogation in the COCZ.

\section{Structural determinism in the Church of Christ in Zimbabwe}

The encumbered values in the COCZ determining religiosity and spirituality need to be re-examined in relationship to entitlements. Structure categorises values that protect interests. Critical Entitlement Theory interrogates these structural dimensions to assess how religious conservatism is instructive on the entitlement outcome. Conservatism is in the contemporary COCZ as the church is characterised by a strong religious-traditional culture, biblical textual literalism and certitude on use of mission stations for evangelism and church growth. Biblical interpretation in the COCZ tends to be highly structured, literal, culturebound and misogynist (Machingura \& Nyakuhwa 2015:92ff). This opposes the founding principles of the Restoration faith based on the Baconian principles of interpretation (Casey 2001:151-66). Baconian philosophy is no longer a single interpretive-hermeneutical principle because African philosophy is unavoidable (Casey 2001:151-166). Patriarch in African philosophy accepts difference as opposed to western paternalism (Masengwe \& Magwidi 2021). Western paternalism has rationalised COCZ religiosity along formalist structures in instruction and practice, which undermines universal values of salvation, mission and ministry by all believers. With African philosophy, these values entrench accountability and responsibility (Mills 1983:15). Missionaries divided followers by undermining accountability and emphasising faithfulness to human paternity (Dowling 2011:73).

Substantive changes in the transformation of the COCZ were suggested concerning church laws or policies and governing structures, leadership, membership and services (Sibanda 2016). Changes are important for thought and action on faith dialogues, power differences and systematic inequalities (Machingura \& Nyakuhwa 2015). The past has not been good for the marginalised (Masengwe et al. 2012). It ignored Restoration history where trappings of denominationalism denied 'modern church Sessions, Presbyteries, Synods, General Assemblies, etc.' (DeGroot 1956:2). Biblical interpretation became localised and contextualised. This did not however imply uncooperativeness, isolation, separation and division found in contemporary churches (DeGroot 1956:3; Dowling 2011:119). Contemporary challenges in mission stations thus need to be analysed using CET.

\section{A multidisciplinary approach in the Church of Christ in Zimbabwe}

Critical Entitlement Theory in this study is used to probe into the convolutions of religious thinking and the recesses of difference that hypothesise, narrate, identify and illustrate new religious scholarship in the COCZ. Gift Masengwe's 
PhD thesis, entitled 'The Church of Christ in Zimbabwe: Mission and Identity Continuity [in Diversity]' (2020), serves as a first serious review of the COCZ transformation on the church's teaching and ministry on different perspectives of the church's application of religious reasoning and decisionmaking. Critical Entitlement Theory standardises reflection on narratives by missionary conduits who always promise foreign generous funding to bail out the ever-bankrupt COCZ. It reviews how narratives, stories and allegories are used to undermine transformation (Masengwe \& Chimhanda 2019, 2020).

The CET further reviews sets of church laws such as the constitution. Written and unwritten constitutions advance inequality and segregation and serve interests elites in the COCZ. Covenanting to assist people who are not in decisionmaking destroys their agency in all things, making them consumers of charity, the way they were treated by missionaries (CBACC 1948-1965). Africans were regarded as having depreciated racial-cognitive incompetence from the Darwinian theories hence had to accept mature decisions made for them. The 1972 undisclosed COCZ constitution is said to have had this inscription. Minutes kept at Colen Brander Church of Christ (CBSCC 1948-1965) indicate that missionaries ordered black people to perform special services and live ethically as expected by the government.

On the contrary, some missionaries such as Garfield Todd, John White, Shirley Cripps, Bishop Dodge and Grace Todd, lobbied for black agency and suffered for it (Casey 2007; Chigwedere 2017; White 2015; Woodhouse 2018). Todd supported the Zimbabwean armed liberation struggle (Mungazi 1999) because Africans constituted the critical workforce for Zimbabwe's thriving enterprises (Woodhouse 2018:330). Africans lived in reserves, as reserved white labour (Woodhouse 2018:86). Liberating them would diminish white privilege and distract white supremacy on jobs, opportunities and resources (Mlambo 1972). Thus, after the 1965 Unilateral Declaration of Independence (UDI), brute force was used against protesters. Critical Entitlement Theory examines why Africans gained political independence, but retained religious colonisation in the COCZ (Wood 2005).

\section{Contextualisation in the Church of Christ in Zimbabwe}

Contextualisation is a common feature in the COCZ as adapting to new changes by being open to new truth whilst upholding the restoration principles that always supported Christian unity and ecumenism (Garrison 1906:127-207). Contextualisation, incarnation and evangelisation are mutually inclusive terms that are not identical with an implication on the full inculturation of the Gospel in an African context. In this way, living life in the church is not worthy living until the church is fully inculturated (Masengwe 2020). This connects a believer to the original Church of Christ through going back to the founding roots (Latin, aggiornamento) as it lives in continuity and discontinuity with what Christ established on Pentecost (Masengwe 2020). Thus,
Alfred Loisy (died 1940), a 20th-century Roman Catholic theologian, argued that 'Christ established the kingdom but what came out was the church, which is found nowhere' (Loisy 1929:153). Going back to the roots assists because the COCZ came in European garb, it needs to be inculturated to become African, rooted in the African cultural context (Williams et al. 2013:3). Mission stations were modelled along American and European institutions (Turner 1920:2) and to carry the Great Commission they need to be transformed. Racial superiority emerged with the economic boom and city life in the United States of America (Garrison 1931:49-58). It was carried into the mission field without consideration of local values. In Africa, unfortunately, communalism naturally and successfully drives the church towards ecumenism and Christian unity (Lipscomb 1916:19-29, 58-64); the only tests of a true Christian church (Blowers, Foster \& Williams 2004:xxx-xxxi; Williams et al. 2013:6).

\section{Paternalism and the constitution in the Church of Christ in Zimbabwe}

The 2015 inclusive and democratic national constitution of the COCZ promised to uphold freedom, dignity and identity of all believers in that Church. Unfortunately, it has done very little to change the uneasy religious, biblical, theological and spiritual plight of its members. Uneasiness led to national break-ups citing irregularities with leadership practices, constitutional incongruence or church doctrine. Resistance to organisational order was inherited from the founders (of the Victorian culture), who were unaware of future advances and explosions of knowledge on human behaviour and biblical hermeneutics (Johnson 1975:72-73). What founders denied, if they lived up to today such as church governments and laws, they would have recommended them to improve on accountability, leadership, direction and identity (Mills 1983:29) because the lack of administration stagnates numerical, spiritual and material growth at all levels. Breakups cite the acceptance of women in leadership as a key doctrinal issue (Fambisai 2019; Jack 2017; Jazire 2020; Mashura 2019; Tembo 2017).

Intentions on these contentions may be unclear, but money has been used to carry the day, marginalising 'African Church Converts' with no external links (Masengwe et al. 2012). This makes missionary paternalism ubiquitous on inequalities at mission stations in the COCZ. Religious inequalities too are not pointed out in the 2015 COCZ national constitution. Differences in terms of gender, age, race and class are not central questions to merit any thorough analysis (Masengwe et al. 2019:278-289). Critical Entitlement Theory wishes to bracket out all issues of religious inequalities as non-formalist pretensions meriting presence in church processes. Use of undisclosed laws of the failed 1972 constitution undermined the legal acceptance and use of the 2015 constitution of the COCZ by elites. This may have been prompted by the uncertainty associated with change or general fear of it (Mills 1983:17). Local initiatives have not been prioritised, probably because the COCZ apex council 
fails to draw out essential legislative elements that connect people with their constitution. This has advanced systematic exclusions, neglect and restrictions based on difference. This has often advanced arbitrariness in how the Bible is applied, hence it negates analytical reasoning to modes of consciousness in the church.

African philosophy was mentioned in this study and it is of significant value to use in reviewing structural determinism because it introduces alternative epistemology to sources of legislation in church. The 2015 constitution fails to underscore African ideals for local Christians. Failure to be all-inclusive probably testifies to the origin and source of the document (Masengwe \& Chimhanda 2020). The call to return to African humanism vis-à-vis western liberalism can disclose critical challenges of paternalism of the Victorian age. The CET advances awareness that ecclesial value structures built on indigenous norms and intellectual sensibilities naturally produce religious outcomes that protect black interests in mission stations. This mainstream blackness is a standard for biblical interpretation and practice. Missionary paternalism in the COCZ failed to develop an autonomous church that could survive the postmodernist context (Masengwe \& Chimhanda 2019, 2020). Inclusion of African humanism can be connected to the COCZ narrative central to church contextualisation, which is 'a method of telling the stories of those people whose experiences are not often told' (Solórzano \& Yosso 2002:26). In contextualisation, new narratives take centre stage in naming social locations usually occupied by dominant narratives. This addresses the absence of consciousness of difference in the COCZ constitution as potentially disruptive to African philosophy but useful for problematising discourses of difference that privilege dominant sectors of the populace, as well as deepening their consciousness towards religious justice (Masengwe et al. 2019:278-289).

In many instances, individuals were vilified and harshly judged to protect dynasties of ruling elites (Masengwe et al. 2012). Equality before the law did not exist until the 2015 constitution's clarity on disciplinary issues (Article 18: Mediation; Article 19: Disciplinary Action). The constitution addresses unreasonable infringements on members' rights, thus giving people a new place to interrogate their faith confessions (Jazire 2020). Members can now use the constitution to analyse church services, especially those at the marginal outsider status unable to participate in mainstream ecclesial politics (Masengwe et al. 2012). Patriarchy unlike paternalism accepts women's participation in church leadership and services. A historical and social analysis of patriarchy using CET would significantly show the relevance of gender inclusion of black people on the COCZ intellectual heritages. The constitution thus failed to consciously discuss difference and diversity in recognition to value preferences that correlate with sensibilities inextricably linked to contemporary Christian standards (Masengwe \& Magwidi 2021). It fails to take into account the lived experiences, histories, cultural and epistemological traditions of the Shona and Nguni Christians. Insistence on past ideologies in the constitution without qualification perpetuates missionary paternalism that did not believe Africans can be fully Christianised. Intersectional analysis advocated by CET illustrates how religion intersects with existing exclusions in African patriarchy experienced at mission stations using unquestioned formalist approaches of entitlement.

Two cases of inequality in the COCZ constitution need redress: firstly, inclusion of Nguni-Shona elements and, secondly, contextualising the restoration faith. Astonishingly, missionary proxies claimed the constitution was used to create a denomination and to discriminate elites running mission stations (Masengwe \& Chimhanda 2019). Blaming the constitution is unfair because the behaviours and practices of elites during their tenure of leadership of the church turned it into a denomination by denying Christian unity and ecumenism. When their interests could not converge with those of others, they mobilised their constituency to decline church laws unless it privileges them (Masengwe \& Chimhanda 2019).

The constitution rather attempted to restore the Restoration faith, turn a movement into a church, without guaranteeing elites' place on mission stations (Masengwe \& Chimhanda 2019). Mission stations subsidise services and activities of elites, hence CET criticises formalised approach to equality that only protects interests of elites. This is unfair towards formerly marginalised people. If constitutional writers of the 2015 COCZ constitution posed that they were discriminated, when they 'personally contributed $80 \%$ of the material' (Masengwe \& Chimhanda 2019:3), it testifies that the constitution did not achieve the purpose for which it was intended. It, however, benefitted those who were actively engaged in the struggle; hence, there is a need to re-engage the constitution for interest of marginalised Christians.

Restoring lost dignity and identity has no disadvantageous effect on unjustly privileged groups, thus denying constitutional legitimacy for entitlements is unjustifiable and is not a constitutional cogency to protect ill-gotten 'power, privilege and position'. All COCZ churches are attended by black people who have no control over mission stations. Critical Entitlement Theory reconceptualises religious equality in this regard; hence, it suggests that church policies and practices developed from the constitution need scrutiny. This critique probes into other areas of substantive equality that cannot be changed, such as educational qualifications. The constitution confirms the history of mission stations, which validates the flipside of African Christian disadvantage against the practice of missionary privilege. This directly challenges entitlements in missionary paternalism embraced by elites owning and running mission stations. Elites contested for privileges rather than ethical laws (Masengwe \& Chimhanda 2019). This article is the first to challenge the use of entitlements in COCZ institutions as no dialogue, review or debate over 
the issue ever ensued in the vision and history of that church (Johnson 1975:78; Mills 1983:19). This article is concerned about how the marginalised are treated in mission churches.

In terms of the minoritarian rule, the former missionary entitled groups can be rhetorically exposed as disadvantaged even though they continue to control the COCZ's material and intellectual resources. They dominate mission stations by making both policy and administrative decisions without accountability to local bodies and both own and run the same. The CET thus contends that inequalities are often obscured by formalisms of law and reason based on injustices of difference and diversity. The COCZ constitution failed to appreciate how ordinary members benefit from church schools, hospitals and clinics. Therefore, how could a fully qualified medical specialist refuse younger medical professionals to assist in mission hospitals and takeover as he or she retires? Entitlement in the COCZ says that it is the medical superintendent of 'As Who Is' in Zimbabwe who approves new intakes to work with him or her at church hospitals. The same person claims to have been prejudiced by church laws, rather than use the platform to empower ordinary Christians and redress the past imbalances in Church's policies, polities and practices. Unfortunately, studies have shown that there are no tangible results from previously over-privileged black elites (Masengwe et al. 2012). Critical Entitlement Theory honestly identifies, acknowledges and redresses these past injustices posed by race, ethnicity, gender and class (Masengwe \& Chimhanda 2020). It does not only limit the discourse to the past but how they are reproduced. This emphasises on how exclusions were virtually left unchanged by the entitlement discourse since independence.

The COCZ constitution was developed to fill an empty and transitory gap. It was produced according to an individual's preference using the foundations of missionary paternalism. This makes the COCZ constitution incongruent with the interests of its beneficiaries. However, on deficiencies created by the politicisation of the process, the chairperson of the constitutional committee admitted at its acceptance that 'it is not a perfect document, but work in progress' (Mafusire 2015). The constitution helped to end the practice of dividing members along individual missionaries and missionary boards, a practice that had continued to subjugate Africans of the post-missionary era. Autonomy is invasive, but has been kept in the constitution to increase African self-determination rather than disenfranchisement (Masengwe et al. 2012).

The COCZ constitutional provisions are perfunctorily radical towards substantive equality. Critical Entitlement Theory here opens deeper thoughts on this radicalism, asking critical question of mission station ownership and administration in the COCZ. It addresses outcomes of religious injustice as the constitution does not more clearly state its commitment towards that which appropriately serves to say that this law is our archival treasure. The COCZ constitution, however, is pliable and inert with transformative value. Critical Entitlement Theory, however, rejects its cautious and incremental redress of remedying inequality. That is why an interviewee once commented that:

'When we are talking about an insidious practice like gender inequality, we need radical measures to address the misuse of difference and diversity in the Church of Christ in Zimbabwe ... Everything needs to change at once, and at the same time.' (Chikwanda, Tshovani Church of Christ, Male, Pastor, 49 years).

Otherwise the religious system swallows up the small improvements of the Church Council over a period of time.

This article has suffered from the lack of literature on mission stations in the COCZ with regard to church laws and religious equality. The constitution is both a 'method' of religious reasoning and a 'cure' for redressing unjust past exclusions, with possibility for tangible outcomes. This article questions and identifies normative, ontological, conceptual and methodological parameters of entitlement on ownership and administration of COCZ mission stations that can be addressed through a central church board like the national council. Unaddressed problems have silenced, abused and degraded African Christians in the contemporary church (Magwidi 2021). The establishment of the national council to address stated challenges has remained ineffective since 2016 when the constitution was established and not all members have access to the council. Critical Entitlement Theory attempts to end the use of 'power, privilege and position' as religious injustice that entitles and privileges entitled individuals on mission stations in the COCZ (Masengwe \& Chimhanda 2019:1-10).

\section{Concluding remarks}

This study has attempted to establish CET for use in emancipating Christians dominated by missionary paternalism in the COCZ. Critical Entitlement Theory analyses new constructive frameworks, ideological tenets and critical paradigms that inform radical religious critique of the church's vocation on human dignity and identity that incorporates and accommodates experiences of black Christians on mission stations. This tool conforms to interpretive techniques of mainstream religious scholarship. Critical Entitlement Theory deeply reminds us of critique religious ideology of the COCZ, but it threatens us by becoming itself another ideology. As an adaptive methodology, CET embraces dissent and internal discontent to avoid prescriptive forms of consciousness. Paternalism and patriarchy were discussed as being potentially oppressive and liberating. Paternalism is a Western ideology that was perpetuated by the colonial moment of capitalism, liberalism and individualism in the COCZ. Patriarchy is an insidious and adoptable ideology in African religion and culture. These ideologies are important in the history of the COCZ and have to be captured in the governing statutes of the church to address the contemporary needs of Africans. Entitlement has to be reviewed because of the complications it 
has caused on how mission stations are handled. Critical Entitlement Theory urges us to engage radically and critically on thoughts and ethos of the COCZ; hence, the adoption of CET in COCZ mainstream religious scholarship becomes a potentially transformative genre that continually reproduces, certifies, justifies and problematises entitlements on mission stations in the COCZ. This promises to liberate ordinary Christians to eventually takeover and run mission stations to benefit the local church through ownership and management by indigenous leaders. Critical Entitlement Theory is a concept that has to be examined and accepted for use in the COCZ to address systematic exclusions and deep inequalities at mission stations in that church. In all, CET liberates COCZ Christians to explore their resources for evangelism, leadership and discipleship towards building comprehensive church institutions.

\section{Acknowledgements \\ Competing interests}

The authors have declared that no competing interests exist.

\section{Authors' contributions}

G.M. and B.D. contributed equally to this work.

\section{Ethical considerations}

This article followed all ethical standards for research without direct contact with human or animal subjects.

\section{Funding information}

This work was supported by the National Research Fund: TTK200318509938.

\section{Data availability}

The authors confirm that the data supporting the findings of this study are available within the article.

\section{Disclaimer}

The views and opinions expressed in this article are those of the authors and do not necessarily reflect the official policy or position of any affiliated agency of the authors.

\section{References}

Banana, C.S., 1991, Come and share: An introduction to Christian Theology, Mambo Press, Gweru.

Barclay, W., 1955, A New Testament Wordbook, S.C.M. Press, London.

Blowers, P.M., Foster, D.A. \& Williams, D.N., 2004, 'Stone-Campbell history over three centuries: A survey and analysis', in D.A. Foster, A.L. Dunnavant, P.M. Blowers \& D.N. Williams (eds.), The encyclopedia of the Stone-Campbell movement, Wm. B. Eerdmans Publishing, London.

Bowen, K., 1996, Evangelism and apostasy: The evolution and impact of evangelicals in modern Mexico, McGill-Quenn's University Press, Montreal.

Calmore, J., 1992, 'Critical race theory, Archie Shepp, and fire music: Securing an authentic intellectual life in a multicultural world', Southern California Law Review 65, 2129-2231

Casey, M.W., 2001, 'From British Ciceronianism to American Baconianism: Alexander Campbell as a case study of a shift in rhetorical theory', Southern Communication Journal 66(2), 151-166. https://doi.org/10.1080/10417940109373194
Casey, M.W., 2004, "'Come let us reason together": The heritage of the Churches of Christ as a source for rhetorical invention', Rhetoric and Public Affairs 7(4), 487-498. https://doi.org/10.1353/rap.2005.0024

Casey, M.W., 2007, The rhetoric of Sir Garfield Todd: Christian imagination and the dream of an African democracy, Balor University Press, Waco, TX.

ColenBrander Avenue Church of Christ (CBACC), 1948-1965, Minute Book [1948-1965], ColenBrander Avenue Church of Christ, Bulawayo.

Chigwedere, A.S., 2017, The White Heroes of Zimbabwe: John White, Arthur Shearly Cripps, Reginald Garfield Todd, Jean Grace Todd, Mutapa Publishing House, Harare.

Church of Christ in Zimbabwe (COCZ), 2015, The Constitution of the Church of Christ in Zimbabwe, Somabhula Conference Centre, Somabhula.

Cornell, D., 2011, 'Revisiting "beyond accommodation" after twenty years', Feminists @ Law 5, viewed 06 October 2020, from http://journals.kent.ac.uk/index.php/ feministsatlaw/issue/current.

Cornell, D. \& Panfilio, K.M., 2010, Unfree Black Labor: The Telos of History and the Struggle against Racialized Capitalism', in D. Cornell, R. Berkowitz \& K.M. Panfilio (eds.), Symbolic forms for a new humanity: Cultural and racial reconfigurations of critical theory, pp. 125-150, Fordham University Press, New York, NY.

Crenshew, K., 1989, 'Demarginalizing the intersection of race and sex: A Black feminist critique of antidiscrimination doctrine, feminist theory and antiracist politics', University of Chicago Legal Forum 140(1), 139-167.

Crenshaw, K., 1991, 'Mapping the margins: Intersectionality, identity politics, and violence against women of color', Stanford Law Review 43(6), 241-1299. https:// doi.org/10.2307/1229039

Crenshaw, K., 2000, 'The intersectionality of race and gender discrimination', Background paper presented at Expert Group Meeting on Gender and Race Discrimination, November, pp. 21-24.

Crenshaw, K., 2011, 'Twenty years of critical race theory: Looking back to move forward', Connecticut Law Review 43, 1253.

DeGroot, A.T., 1956, Church of Christ number two, The Birmingham Printers' Press, New York, NY.

Delgado, R. \& Stefancic, J., 1993, 'Critical race theory: An annotated biography', Virginia Law Reports 79(2), 461. https://doi.org/10.2307/1073418

Dowling, E.E., 2011, How to be a servant and serve in the Restoration Movement, Christian University, Lincoln.

Dulles, A., 1987, Models of the church, Doubleday, New York, NY.

Fambisai, P., 2019, 'The Christian perspective of the circle of concerned women theologians on gender in the Church of Christ in Zimbabwe', Masters in Religious Studies, Department of Gender Studies, University of Zimbabwe, Harare.

Garrison, J.H., 1906, Christian union: A historical study, Christian Publishing, St. Louis, MI.

Garrison, W., 1961, Heritage and destiny: An American religious movement looks ahead, Bethany Press, St. Louis, MI.

Garrison, W.E., 1931, Religion found in the frontier: A history of the disciples of Christ, Herper Brothers, New York, NY.

Gundani, P., 2008, Church, viewed 25 June 2020, from www.paulgundani.com.

Halencreutz, C.F., 1998, Religion and politics in Harare 1890-1980, Swedish Institute of Missionary Research, Uppsala.

Hooks, B., 1981, Ain't I a woman: Black women and feminism, vol. 3, South End Press, Boston, MA.

Hutchinson, D.L., 2004, Foreword: Critical Race Histories: In and Out. American University Law Review 53, 1187-1207.

Jack, J., 2017, An exploratory study to the challenges being encountered by single women in the Church of Christ in Zimbabwe: A study of the challenge of single women to the life of the Church, Midlands State University, Gweru.

Jansen, J.D., 2009, Knowledge in the blood: Confronting race and the apartheid past, Stanford University Press, Palo Alto, CA.

Jazire, O., 2020, 'The recognition of female ministers in the Church in Zimbabwe with special reference to the Gweru-Kwekwe Church of Christ', BA (Hons.) Religion and Theology, Midlands State University, Gweru.

Johnson, H.E., 1975, The Christian church plea, Standard Publishing, Cincinnati.

Lipscomb, D., 1916, Christian unity: How promoted, how destroyed, McQuiddy Printing, Nashville, TN

Loisy, A., 1929, L'Évangile et l'Église, 5th ed., Émile Nourry, Paris.

Machingura, F. \& Nyakuwa, P., 2015, 'Sexism: A hermetical interrogation of Galatians 3: 28 and women in the Church of Christ in Zimbabwe', The Journal of Pan African Studies 8(2), 92-113.

Mafusire, J., 2015, Church of Christ in Zimbabwe: Report on the constitutional adoption meeting on 19 September 2015, COCZ, Somabhula Conference Centre, Gweru.

Magwidi, E., 2021, 'Leadership Succession in Church and Mission: A comparative study of the succession processes between the Dadaya and Mashoko missions from 1956-2015', PhD thesis, Department of Church History, University of South Africa, Pretoria.

Marle, R., 1968, Bonhoeffer: The Man and his Work, Geoffery Chapman, London.

Masengwe, G., 2020, 'The Church of Christ in Zimbabwe: Identity- and missioncontinuity in diversity', PhD thesis in the Discipline of Systematic Theology, Faculty of Social Sciences, Arts and Humanities, University of South Africa, Pretoria. 
Masengwe, G. \& Chimhanda, F.H., 2019, 'Towards authentic transformation in the Church of Christ in Zimbabwe', HTS Theological Studies 74(1), 1-11. https://doi. org/10.4102/hts.v74i1.4776

Masengwe, G. \& Chimhanda, F.H., 2020, 'Postmodernism, identity and mission continuity in the Church of Christ in Zimbabwe', Verbum et Ecclesia 40(1), 1-10. https://doi.org/10.4102/ve.v41i1.1906

Masengwe, G., Chimhanda, F.H. \& Hove, R., 2019, 'Women, Marginality and the Bible: Sexism in the Church of Christ in Zimbabwe, in BIAS 22: Bible in Africa Studies, pp. 278-289, Bramberg University Press, Bamberg.

Masengwe, G., Machingura, F. \& Magwidi, E., 2012, 'An excavation on church governance: The question of autonomy in the light of the disempowered African church converts in the Church of Christ in Zimbabwe (COCZ)', Journal of Research in Peace, Gender and Development 2(9), 185-194.

Masengwe, G. \& Magwidi, E., 2021, 'Africanising the four-self leadership formula in the Church of Christ in Zimbabwe', Studia Historiae Ecclessiasticae, 47(1), 1-20. https://doi.org/10.25159/2412-4265/8159

Mashura, P., 2019, 'An investigation into the rights of ordination for women in the churches of Christ in Zimbabwe', BA (Hons.) Religious Studies and Theology, Domboshawa Theological Seminary, Harare.

M'Clintock, J.D. \& Strong, J.S., 1969, Encyclopaedia of biblical theological and ecclesiastical literature, vols. I-II, Arno Press, New York, NY.

Mills, C.W., 2003, From class to race: Essays in white Marxism and black radicalism, Rowman \& Littlefield, London.

Mills, J., 1983, History of the open forum on the mission of the Church, Christian churches and churches of Christ, Standard Publishing, Cincinnati, $\mathrm{OH}$

Mlambo, E., 1972, Rhodesia: Struggle for a birthright, C. Hurst, London.

Modiri, J.M., 2011, 'The colour of law, power and knowledge: Introducing critical race theory in (post) apartheid South Africa', South African Journal on Human Rights 28(3), 405-437. https://doi.org/10.1080/19962126.2012.11865054

Mungazi, D., 1999, The last British liberals in Africa: Michael Blundell and Garfield Todd, Praeger, Westport.
Savage, M.J., 1980, Forward into freedom: Continuing the story of missionary endeavor in Zimbabwe and Vanuatu, Associated Churches of Christ in New Zealand (ACCNZ) Publications, Perth.

Sibanda, T., 2016, 'An Investigation into the Significance of the Church of Christ in Zimbabwe's National Administrative Operational Structure (NAOS) from 2015-2018', Ziploma in Church Administration and Manegement (DSCAM), Ecumenical Resources Training Centre (ERTC), Zimbabwe Council of Churches, Harare.

Solórzano, D.G. \& Yosso, T.J., 2002, 'Critical race methodology: Counter-storytelling as an analytical framework for education research', Qualitative Inquiry 8(1), 23-44. https://doi.org/10.1177/107780040200800103

Tembo, B.R., 2017, An analysis of the role of Christian women's groups in advocating for gender sensitivity with special reference to women in the Bulawayo Churches of Christ, Zimbabwe Christian College, Harare.

Turner, F.J., 1920, The frontier in American history, Henry Holt, New York, NY.

Van Reken, C.P., 1999, 'The church's role in social justice', Calvin Theological Journal 34, 198-202.

Villa-Vicencio, C. (ed.), 1986, Between Christ and Caesar: Classic and contemporary texts on church and state, New Africa Books, Cape Town.

White, L., 2015, Unpopular sovereignty: Rhodesian independence and African decolonization, University of Chicago Press, Chicago, IL.

Williams, D.N., Foster, D.A. \& Blowers, P. (eds.), 2013, The Stone-Campbell Movement: A global history, Chalice Press, St Louis, MI.

Williams, H., 2003, 'That's the way we've always done it': The myth of progress and the identity of women in Baptist life, Florida State University Press, Gainesville, FL.

Wing, A., 2008, 'The South African Constitution as a role model for the United States', Harvard Blackletter Law Journal 24, 73.

Wood, J.R.T., 2005, So far and no further! Rhodesia's bid for independence during the retreat from empire 1959-1965, Tafford Publishing, Victoria, BC.

Woodhouse, S., 2018, Garfield Todd: The end of the liberal dream in Rhodesia, Weaver Press, Harare. 